\title{
PENERAPAN PEMBERIAN KUIS DI AKHIR PELAJARAN UNTUK MENINGKATKAN HASIL BELAJAR SISWA PADA POKOK BAHASAN MANUSIA DAN LINGKUNGAN KELAS VII SMP 02 IBNU SINA KABIL BATAM
}

\section{THE APPLICATION OF LAST MINUTES' QUIZ TO IMPROVE STUDENT LEARNING OUTCOMES ON HUMAN AND ENVIRONMENTAL MATERIAL AT CLASS VII SMP 02 IBNU SINA KABIL BATAM}

\author{
Mellisa Hermonita ${ }^{1}$, Destaria Sudirman ${ }^{2}$, Rahmi Rahmi ${ }^{3}$ \\ ${ }^{1,2,3}$ Program Studi Pendidikan Biologi, FKIP, Universitas Riau Kepulauan, Batam \\ "Koresponden: destaria_sudirman@yahoo.com
}

\begin{abstract}
Abstrak
Penelitian ini dilaksanakan di SMP 02 Ibnu Sina Kabil Batam, bertujuan untuk mengetahui apakah penerapan pemberian kuis pada akhir pelajaran di sekolah dapat meningkatkan hasil belajar siswa dalam pembelajaran biologi. Penelitian ini menggunakan desain Penelitian Tindakan Kelas (PTK), yang terdiri dari tiga siklus yaitu; perencanaan, pelaksanaan, observasi dan refleksi, dengan subyek adalah siswa kelas VII B berjumlah 37 siswa. Hasil penelitian menunjukkan bahwa pemberian kuis pada akhir pelajaran dapat meningkatkan hasil belajar siswa. Hal ini dapat dilihat dalam pelaksanaan siklus pertama nilai rata-rata 73,24\%, siklus kedua terjadi namun penurunan dengan selisih sebesar 1,89\% atau menjadi ke $71,35 \%$. Siklus ketiga ada peningkatan dari $24,32 \%$ secara nyata menjadi $95,67 \%$.
\end{abstract}

Kata Kunci: PTK, Kuis, Hasil belajar siswa

\section{Abstract}

The research was conducted at SMP 02 Ibnu Sina Kabil Batam, which aims to determine whether the application of last minutes' quiz at schools can improve students' learning outcomes on learning biology. This study used Class Action Research (CAR), which consists of three cycles namely; planning, implementation, observation and reflection. Class VII B with amount to 37 students as subject. The results showed that last minutes' quiz can improve students' learning outcomes. It can be seen in the implementation of the first cycle of with the average value at $73.24 \%$, the second cycle occurred but declines by a margin at $1.89 \%$ or to $71.35 \%$. The third cycle there is a significantly increasing at $24.32 \%$ be $95.67 \%$

Keywords: CAR, Quizzes; Students' learning outcomes.

\section{PENDAHULUAN}

Secara umum masalah yang dihadapi dunia pendidikan kita adalah lemahnya proses pembelajaran. Dalam proses pembelajaran, siswa cenderung kurang didorong untuk mengembangkan kemampuan berpikir, sehingga proses pembelajaran di kelas hanya diarahkan untuk menghafal dan mengingat informasi ilmu. Otak dipaksa untuk mengingat, menghafal, dan menimbun informasi dimana para siswa lebih menguasai 
teoritis materi pelajaran dibandingkan dengan mengaplikasinya dalam kehidupan sehari-hari. Dalam hal ini tidak sesuai dengan tujuan pendidikan yaitu kegiatan belajar dan mengajar yang diarahkan untuk pembentukan mental, penciptaan lingkungan belajar yang dapat mempengaruhi pengembangan kognitif siswa dan membantunya agar lebih sadar terhadap proses berfikirnya, misalnya dalam hal kemampuan dasar siswa, pengetahuan, sikap dan motivasinya.

Banyak diantara siswa yang berpendapat bahwa belajar biologi membosankan, karena pelajaran biologi merupakan pelajaran hafalan. Biologi adalah ilmu pengetahuan alam yang perlu dipelajari dan dipraktekkan secara langsung. Menanggapi keadaan yang seperti itu seorang guru dituntut untuk pandai dan berpikir kreatif dalam menentukan metode dan cara dalam melaksanakan tugas mengajar siswa supaya tercapai dan terpenuhi apa yang menjadi tujuan pembelajaran. Salah satunya adalah dengan memberikan kuis pada siswa sehingga siswa terpacu untuk mengikuti pembelajaran dengan baik dan memperhatikan setiap materi yang disampaikan guru. Kuis dapat diberikan pada akhir pelajaran ataupun awal pertemuan berikutnya agar pelajaran yang diperoleh pada pertemuan sebelumnya dapat diingat dan tidak terlupakan begitu saja.

Metode pemberian kuis diharapkan dapat dijadikan sebagai alternatif metode pembelajaran yang berpengaruh terhadap hasil belajar siswa, karena dengan diadakannya kuis baik pada awal pembelajaran ataupun di akhir pembelajaran siswa akan terlebih dahulu mempelajari materi baik yang telah disampaikan maupun yang akan disampaikan, sehingga kegiatan belajar mengajar dapat lebih efektif dan efisien. Tujuan dari penelitian ini adalah untuk mengetahui apakah penerapan pemberian kuis di akhir pelajaran dapat meningkatkan hasil belajar siswa kelas VII SMP 02 IBNU SINA Kabil Batam dalam pembelajaran biologi.

\section{METODOLOGI}

Penelitian ini menggunakan metode penelitian tindakan kelas (Classroom Action Research) yang telah dilaksankan selama tiga bulan, yaitu dari bulan April sampai dengan bulan Juni 2013 dengan subyek penelitian siswa kelas sebanyak 37 orang yang terdiri dari 23 siswi perempuan dan 14 siswa laki-laki. Penelitian ini dilakukan sebanyak tiga siklus, masing-masing siklus 1x pertemuan. Siklus I menjelaskan 
pengertian penduduk dan kepadatan populasi hubungannya dengan lingkungan, siklus II menjelaskan pencemaran dan kerusakan lingkungan hubungannya dengan aktivitas manusia, dan siklus III mengulang kembali materi yang telah dijelaskan pada materi pertama dan kedua guna melihat peningkatan hasil belajar siswa. Waktu belajar efektif sebanyak 3 x 40 menit. Pelaksanakan penelitian tindakan kelas dengan prosedur adalah sebagai berikut: perencanaan, pelaksanaan tindakan, evaluasi/pengamatan tindakan, refleksi terhadap tindakan. Evaluasi nilai berdasarkan kriteria ketuntasan minimal (KKM) yang di tetapkan untuk mata pelajaran biologi adalah dengan points 70 . Jika peserta didik mencapai skor ketuntasan 75\%, maka secara individual dapat dikatakan bahwa peserta didik tersebut telah lulus dan dapat melanjutkan ke tingkat yang lebih tinggi. Data dalam PTK adalah segala bentuk informasi yang terkait dengan kondisi, proses, dan keterlaksanaan pembelajaran, serta hasil belajar yang diperoleh siswa. Analisis kesimpulan tentang keberhasilan tindakan perbaikan. dari sumber data dapat dikelompokkan menjadi dua, yaitu data kualitatif dan data kuantitatif. Serta ada penilaian tambahan dari Guru yang akan menjadi observer pada penelitian ini sesuai dengan bidang studi Biologi

\section{PEMBAHASAN}

Hasil analisis data-data kuantitatif dan data kualitatif yang dilakukan dalam tiga siklus. Pada setiap siklus, data yang diambil adalah aktivitas belajar siswa di kelas dan nilai evaluasi siswa yang berupa kuis pada setiap akhir pertemuan serta meliput data tentang keaktifan siswa dengan melakukan cek list tentang keaktifan siswa. Pada awal pertemuan, sebelum pemberian materi/tindakan peneliti membagikan lembar pretest yang berupa pernyataan dengan pilihan jawaban benar atau salah untuk mengetahui hasil belajar siswa sebelum diberi tindakan. Setelah itu peneliti memberi perlakuan dengan menyampaikan materi yang terkait, kemudian peneliti kembali membagikan lembar tes yang berupa kuis yang sama dengan pretest berupa pernyataan dengan pilihan jawaban benar atau salah. Hasil observasi aktivitas siswa dari siklus ke siklus sebagai berikut: 
Tabel 1. Data aktivitas siswa dalam pembelajaran

\begin{tabular}{|c|c|c|c|c|}
\hline \multirow[t]{2}{*}{ No } & \multirow[t]{2}{*}{ Indikator } & \multicolumn{3}{|c|}{ Ketercapaian } \\
\hline & & Siklus I & Siklus II & Siklus III \\
\hline 1. & $\begin{array}{l}\text { Keterampilan siswa dalam menyelesaikan soal- } \\
\text { soal yang diberikan pada awal pertemuan. }\end{array}$ & $8.10 \%$ & $8.10 \%$ & $8.10 \%$ \\
\hline 2. & $\begin{array}{l}\text { Ketertarikan siswa memperhatikan penjelasan } \\
\text { guru terkait materi pelajaran "manusia dan } \\
\text { lingkungan". }\end{array}$ & $10.81 \%$ & $10.81 \%$ & $13.51 \%$ \\
\hline 3. & $\begin{array}{l}\text { Siswa berpikir kreatif untuk memahami materi } \\
\text { pelajaran "manusia dan lingkungan" }\end{array}$ & $5.40 \%$ & $8.10 \%$ & $10.81 \%$ \\
\hline 4. & $\begin{array}{l}\text { Siswa berpikir kritis untuk memahami materi } \\
\text { pelajaran "manusia dan lingkungan" }\end{array}$ & $8.10 \%$ & $8.10 \%$ & $8.10 \%$ \\
\hline 5. & $\begin{array}{l}\text { Menunjukkan antusiasme/minat terhadap } \\
\text { kegiatan pembelajaran dengan mengajukan } \\
\text { masalah/pertanyaan. }\end{array}$ & $2.70 \%$ & $8.10 \%$ & $10.81 \%$ \\
\hline 6. & Kemampuan siswa mengemukakan pendapat & $2.70 \%$ & $8.10 \%$ & $8.10 \%$ \\
\hline 7. & $\begin{array}{l}\text { Kemampuan siswa menunjukkan berbagai } \\
\text { strategi memecahkan masalah. }\end{array}$ & $10.81 \%$ & $8.10 \%$ & $8.10 \%$ \\
\hline 8. & $\begin{array}{l}\text { Siswa menunjukkan proses yang efisien dalam } \\
\text { menyelesaikan masalah. }\end{array}$ & $8.10 \%$ & $8.10 \%$ & $10.81 \%$ \\
\hline 9. & $\begin{array}{l}\text { Kemampuan siswa mengerjakan latihan soal } \\
\text { yang diberikan oleh guru pada akhir } \\
\text { pembelajaran. }\end{array}$ & $8.10 \%$ & $10.81 \%$ & $13.51 \%$ \\
\hline 10. & $\begin{array}{l}\text { Siswa mengomentari dan menyimpulkan proses } \\
\text { pembelajaran. }\end{array}$ & $10.81 \%$ & $10.81 \%$ & $10.81 \%$ \\
\hline 11. & $\begin{array}{l}\text { Siswa memperbaiki kesalahan atau kekurangan } \\
\text { dalam proses pembelajaran. }\end{array}$ & $5.40 \%$ & $10.81 \%$ & $8.10 \%$ \\
\hline 12. & $\begin{array}{l}\text { Kemampuan siswa menyimpulkan materi } \\
\text { pembelajaran dengan kata-katanya sendiri. }\end{array}$ & $5.40 \%$ & $8.10 \%$ & $13.51 \%$ \\
\hline & Jumlah & $86.43 \%$ & $108.04 \%$ & $124.27 \%$ \\
\hline & Rata-rata & $7.20 \%$ & $9.03 \%$ & $10.35 \%$ \\
\hline
\end{tabular}

Berdasarkan tabel 1 diatas, dilihat dari jumlahnya aktivitas siswa yang relevan dengan kegiatan pembelajaran pada siklus II dan III mengalami peningkatan dibandingkan dengan siklus I. Pada siklus I jumlah yang didapat $86.43 \%$, siklus II meningkat sebesar $21.61 \%$ menjadi $108.04 \%$ dengan perbandingan rata-rata $1.83 \%$. Pada siklus III meningkat lagi sebesar $16.23 \%$ menjadi $124.27 \%$ dengan perbandingan rata-rata $1.32 \%$. Hal ini menunjukkan ada peningkatan dari cara belajar siswa; siswa terampil dalam mengerjakan soal-soalnya sendiri, siswa sudah mulai berpikir kreatif dan kritis untuk memahami materi pelajaran, minat siswa terhadap kegiatan pembelajaran sudah mulai tampak dengan mengajukan pertanyaan dan mengemukakan pendapat. Penerapan pemberian kuis dapat menciptakan pembelajaran yang lebih aktif. Lesy Luzyawati (2008) menyatakan bahwa "yang dimaksud dengan aktif adalah proses pembelajaran dimana guru harus menciptakan suasana sedemikian rupa sehingga siswa 
aktif bertanya, mempertanyakan, dan mengemukakan pendapatnya". Belajar merupakan suatu proses aktif dari siswa dalam membangun pengetahuannya, bukan proses pasif yang hanya menerima kucuran ceramah tentang pengetahuan.

Selanjutnya data pemahaman siswa tentang pembelajaran biologi yaitu materi manusia dan lingkungan dan ketuntasan belajar siswa dari siklus ke siklus dapat dilihat pada tabel 2 sebagai berikut:

Tabel 2. Data pemahaman siswa dan ketuntasan belajar siswa

\begin{tabular}{|c|c|c|c|c|}
\hline \multirow{2}{*}{ No } & \multirow{2}{*}{ Aspek Yang Diamati } & \multicolumn{3}{|c|}{ Ketercapaian } \\
\hline & & Siklus I & Siklus II & Siklus III \\
\hline 1. & Nilai rata-rata pemahaman materi & $73.24 \%$ & $71.35 \%$ & $95.67 \%$ \\
\hline 2. & Siswa yang telah tuntas & $89.18 \%$ & $78.37 \%$ & $100 \%$ \\
\hline 3. & Siswa yang belum tuntas & $10.81 \%$ & $21.62 \%$ & - \\
\hline
\end{tabular}

Berdasarkan tabel 2 diatas, nilai rata-rata pemahaman siswa tentang pelajaran biologi materi manusia dan lingkungan tidak mengalami peningkatan dari siklus I ke siklus II, persentase yang didapat pada siklus I sebesar 73,24\%, pada siklus II menurun sebesar $1.89 \%$ menjadi $71.35 \%$, tetapi dari siklus II ke siklus III mengalami peningkatan sebesar $24.32 \%$ menjadi $95.67 \%$. Begitu juga persentase siswa yang mencapai ketuntasan belajar tidak ada peningkatan yang signifikan, dari siklus I ke siklus II, persentase yang didapat pada siklus I sebesar $89.18 \%$, pada siklus II terjadi penurunan sebesar $10.81 \%$ menjadi $78.37 \%$, tetapi dari siklus II ke siklus III tampak peningkatan yang nyata sebesar $21.63 \%$ menjadi $100 \%$. Sama hal dengan siswa yang belum tuntas, pada siklus I siswa yang belum tuntas adalah $10.81 \%$, pada siklus II siswa yang belum tuntas malah meningkat sebesar $10.81 \%$ menjadi $21.62 \%$, tetapi pada siklus III sudah tidak ada lagi siswa yang tidak tuntas.

Dari Gambar 1. menunjukkan bahwa penerapan pemberian kuis di akhir pelajaran mampu meningkatkan hasil belajar siswa. Hal ini dapat dilihat pada pelaksanaan siklus I nilai rata-rata siswa $73.24 \%$, siswa yang telah tuntas $89.18 \%$, dan siswa yang belum tuntas $10.81 \%$ dikarenakan siswa mengalami kesulitan dalam menjawab soal kuis yang berbentuk pernyataan pada siklus I.

Pada siklus II nilai rata-rata siswa turun menjadi $71.35 \%$, siswa yang telah tuntas pun menurun menjadi 78.37\%, dengan demikian siswa yang belum tuntas meningkat menjadi $21.62 \%$ ini dikarenakan siswa masih banyak mengalami kesulitan dalam menjawab kuis, hal ini dapat disebabkan karena soal yang diberikan berupa 
pernyataan dengan pilihan jawaban benar atau salah sehingga soal agak membingungkan dan para siswa ragu-ragu dalam memilih jawaban benar atau salah. Tetapi pada siklus III terjadi kenaikan yang signifikan, nilai rata-rata siswa naik sebesar $24.32 \%$ menjadi $95.67 \%$, siswa yang telah tuntas pun naik menjadi $100 \%$, pada siklus ini siswa lebih memperhatikan penjelasan peneliti dan keaktifan siswa dalam bertanya dan menjawab pertanyaan lebih ditingkatkan lagi sehingga para siswa dapat menjawab kuis yang diberikan dengan mudah dan yakin.

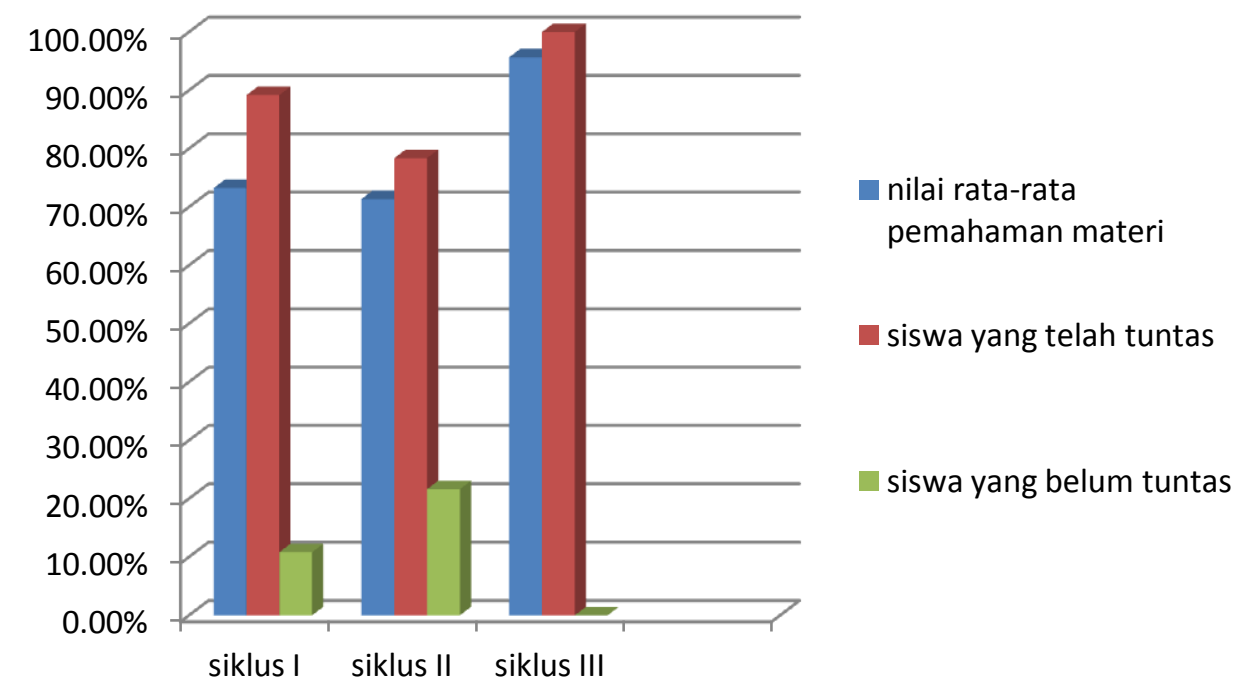

Gambar 1. Histogram pemahaman siswa dan ketuntasan belajar siswa secara keseluruhan

Hasil penelitian ini menunjukkan bahwa penerapan pemberian kuis diakhir pelajaran mampu meningkatkan hasil belajar siswa. Dapat dilihat pada hasil kuis siswa. Nilai rata-rata siswa pada siklus I adalah 81.62, pada siklus II nilai rata-rata siswa meningkat sebesar 9.46 menjadi 91.08, dan pada siklus III nilai rata-rata siswa kembali meningkat sebesar 4.59 menjadi 95.67. Hasil tersebut sejalan dengan pendapat Mulyasa (2005) yang menyatakan "suatu pembelajaran dapat dikatakan berhasil apabila seluruh atau setidak-tidaknya sebagian besar (75\%) peserta didik terlibat secara aktif baik fisik, mental maupun sosial dalam proses pembelajaran".

Merujuk Tabel 2 diatas, nilai rata-rata pemahaman siswa tentang pelajaran biologi siklus II terjadi penurunan sebesar $1.89 \%$ dari $73.24 \%$ pada siklus I menjadi $71.35 \%$ pada siklus II dan siswa yang telah tuntas pun menurun sebesar $10.81 \%$ dari 89.18\% pada siklus I menjadi $78.37 \%$ pada siklus II. Hal ini dikarenakan siswa masih 
banyak mengalami kesulitan dalam menjawab kuis dan dapat disebabkan karena kuis yang diberikan berupa pernyataan dengan pilihan jawaban benar atau salah sehingga soal membingungkan dan para siswa ragu-ragu dalam memilih jawaban benar atau salah. Hasil penelitian ini tetap dikatakan berhasil dan menunjukkan bahwa penerapan pemberian kuis diakhir pelajaran mampu meningkatkan hasil belajar siswa. Mohammad Asrori (2009) menyatakan "apabila keadaan setelah tindakan lebih baik, maka dapat dikatakan bahwa tindakan telah berhasil. Sebaliknya, apabila tidak ada perbaikan atau bahkan lebih jelek, maka berarti tindakan yang dilaksanakan belum berhasil atau bahkan gagal".

Pada akhir siklus II dilakukan refleksi yang dipergunakan untuk perbaikan dalam rencana tindakan pada siklus selanjutnya. Hasil refleksi siklus II menunjukkan adanya kesulitan dalam menjawab soal pada kuis yang disebabkan soal berbentuk pernyataan sangat menjebak. Pada rencana siklus selanjutnya peneliti mengharapkan agar siswa lebih memperhatikan penjelasan peneliti dan keaktifan siswa dalam bertanya dan menjawab pertanyaan lebih ditingkatkan lagi sehingga para siswa dapat menjawab kuis yang diberikan dengan mudah dan yakin. Setelah memberikan perlakuan dari perbaikan siklus II, nilai rata-rata pemahaman materi yang diperoleh pada siklus III pun meningkat sebesar $24.32 \%$ menjadi $95.67 \%$ dan siswa yang tuntas pun meningkat sebesar $21.63 \%$ menjadi tuntas $100 \%$.

Dengan demikian melalui penerapan pemberian kuis di akhir pelajaran guru dapat mengamati karakteristik atau gaya belajar masing-masing siswa. Ada kelompok siswa yang dengan lugas dan lincah mampu memecahkan masalah secara rasional, ada juga kelompok siswa yang hanya mendengarkan apa yang disampaikan oleh guru.

Berdasarkan hasil penelitian tindakan kelas diatas, presentasi ketercapaian pada siklus I mengalami peningkatan yang signifikan pada siklus II dan siklus III dilihat reratanya. Maka dapat disimpulkan bahwa temuan pada penelitian menjawab hipotesis bahwa penerapan pemberian kuis di akhir pelajaran dapat meningkatkan hasil belajar siswa dalam mata pelajaran manusia dan lingkungan kelas VII.

\section{KESIMPULAN}

Berdasarkan hasil pengamatan menunjukkan bahwa tanpa pemberian kuis diakhir pelajaran rata-rata hasil belajar hanya dengan nilai 61.27 dan ketuntasan belajar 
40\%. Setelah diterapkan dengan cara PTK maka pemberian kuis diakhir pelajaran dengan nilai rata-rata hasil belajar siswa pada siklus I meningkat menjadi $81.62 \%$ dengan ketuntasan belajar $89.18 \%$. Pada siklus II nilai rata-rata hasil belajar siswa mencapai $91.08 \%$ dengan ketuntasan belajar $78.37 \%$. Sedangkan pada siklus III, nilai rata-rata hasil belajar siswa mencapai $95.67 \%$ dengan ketuntasan belajar 100\%.

\section{REFERENSI}

Arikunto, S. 2008. Penelitian Tindakan Kelas. Bumi Aksara. Jakarta.

Asrori, M., 2009. Penelitian Tidakan Kelas. CV Wacana Prima. Bandung.

Dimyati, M., 2006. Belajar dan Pembelajaran. PT. Rineka Cipta, Jakarta.

Hamalik, O., 2008. Proses Belajar Mengajar. Bumi Aksara, Jakarta.

Prabowo, 2001. Prinsip-prinsip Penelitian Tindakan Kelas. Jakarta

Rama, T. K., 1991. Kamus Praktis Bahasa Indonesia. Karya Agung, Surabaya.

Ridwan, 2005. Skala Pengukuran Variabel-Variabel Penelitian. Alfabeta, Bandung.

Sudjana, 2005. Penilaian Hasil Proses Belajar Mengajar. PT. Remaja Rosdikarya, Bandung.

Suhardjono, 2007. Penelitian Tindakan Kelas. Bumi Aksara, Jakarta.

Tim Reality. 2009. Tim Reality Kamus Biologi. Reality Publisher, Surabaya.

Wahidmurni, 2008. Penelitian Tindakan Kelas. UM Press, Malang.

Zainal, A., 2007. Penelitian Tindakan Kelas. Yrama Wida, Bandung. 